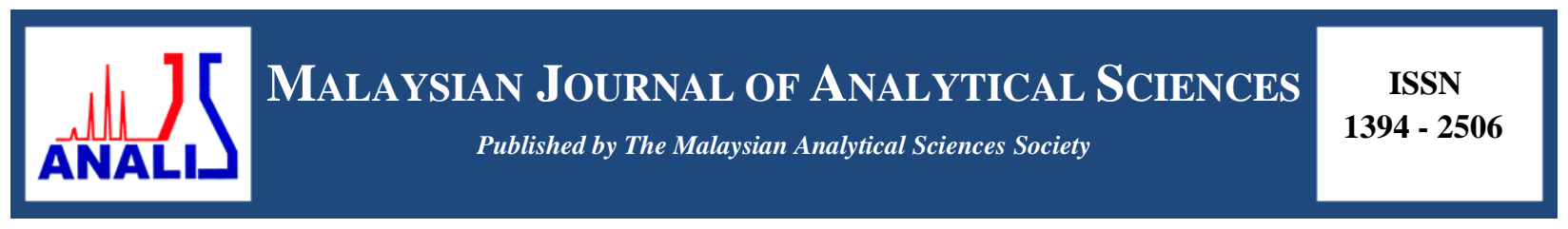

\title{
QUANTIFICATION OF GROUNDWATER-DERIVED NUTRIENTS INTO BEACH RIDGE DRAINAGE USING RADON MASS BALANCE MODEL
}

\author{
(Kuantifikasi Nutrien Air Bawah Tanah ke Saluran Pematang Pasir dengan Model \\ Keseimbangan Jisim Radon) \\ Nicholas Chia Wei Ng and Seng-Chee Poh* \\ School of Marine and Environmental Sciences, \\ Universiti Malaysia Terengganu, 21030 Kuala Nerus, Terengganu, Malaysia \\ *Corresponding author: poh@umt.edu.my
}

Received: 10 November 2017; Accepted: 22 May 2018

\begin{abstract}
Groundwater discharge can be a significant pathway for dissolved nutrients to surface water and thus can bring forth important implications to the coastal biogeochemical cycles. Discrete sampling of radon concentrations at several locations along an interridge drainage off Setiu Wetlands were carried out to estimate the fluxes of groundwater discharge. The ${ }^{222} \mathrm{Rn}$ mass balance results show that groundwater discharge in the drainage is estimated to be $6649 \mathrm{~m}^{3} \mathrm{day}^{-1}$, made up of $\sim 33 \%$ of total water discharge and has contributed $2.88 \times 10^{2}$ molday $^{-1}, 1.23 \times 10^{2}$ molday $^{-1}$ and 0.75 molday $^{-1}$ of ammonium-nitrogen, nitrate-nitrogen and nitrite-nitrogen, respectively into the surface water drainage. Strong correlation between radon and ammonium suggested that the source of nutrient in drainage is groundwater-based, derived probably from the nearby damaged or leaking residential septic tanks and from agricultural practices of oil palm plantation.
\end{abstract}

Keywords: groundwater-surface water interaction, water quality, beach ridge drainage, Setiu, Malaysia

\begin{abstract}
Abstrak
Pelepasan air bawah tanah merupakan satu laluan penting untuk nutrien ke air permukaan. Proses ini mampu membawa implikasi yang penting terhadap kitaran biogeokimia di pesisiran pantai. Pensampelan radon di sepanjang saluran pematang pasir telah dijalankan untuk menentukan kadar pelepasan air bawah tanah. Hasil model keseimbangan jisim ${ }^{222} \mathrm{Rn}$ telah menunjukkan kadar pelepasan air bawah tanah di saluran adalah sebanyak $6649 \mathrm{~m}^{3}$ hari $^{-1}$ dan nilai ini merangkumi $\sim 33 \%$ daripada jumlah pelepasan air. Pelepasan air bawah tanah juga menyumbang sebanyak $2.88 \times 10^{2}$ mol hari ${ }^{-1}$ amonium-nitrogen, $1.23 \times 10^{2}$ mol hari $^{-1}$ nitrit-nitrogen dan 0.75 mol hari $^{-1}$ dan nitrit-nitrogen ke air permukaan saluran. Kolerasi antara kepekatan radon dan ammonium di saluran juga mencadangkan sumber nutrien berasal dari air bawah tanah yang kemungkinan tercemar oleh sisa pembuangan kumbahan dari kawasan kediaman berdekatan dan rembesan pertanian dari ladang kelapa sawit di sekitarnya.
\end{abstract}

Kata kunci: interaksi air bawah tanah-air permukaan, kualiti air, saluran pematang pasir, Setiu, Malaysia

\section{Introduction}

Importance of groundwater discharge as a nutrient source to the river and estuaries are often overlooked. Several studies have demonstrated that groundwater discharge can be a significant contributor of nutrients to the coastal environment and being recognized as a potential pathway for non-point pollution, especially when agricultural practices or urban activities had impacted the groundwater quality [1-4]. Previous studies have shown that radon is a great tool to study groundwater-surface water interaction in different environmental settings [5, 6, 7]. Radon has 
relatively short halve-lives (3.8 days) and low solubility in water, $0.01 \mathrm{molkg}^{-1} \mathrm{bar}^{-1}$ at $293 \mathrm{~K}$ [8]. Radon concentration tend to be higher in groundwater compared to the surface water i.e. lake, river, estuary and ocean. In aquifer, radon concentration in groundwater is proportional to radium-bearing rocks and soils. On contrary, radon concentration in surface water tends to be low due to natural decay, degassing and dilution processes. The large difference in radon concentration between surface and groundwater can be used as a proxy to determine groundwater discharge hotspots $[9,10]$.

Numerous studies have applied ${ }^{222} \mathrm{Rn}$ mass model to assess groundwater discharge in rivers and estuaries [11, 12]. Other studies also incorporate geophysical technique such as seepage meters with ${ }^{222} \mathrm{Rn}$ measurement to examine groundwater discharge into the river [13]. Most of the groundwater discharge studies were carried out in-situ by a portable radon gas detector $[14,15]$. In general, the radon measurement required a headspace equilibrator attached to the radon detector. The equilibrator allows radon gas in water to exchange rapidly with gases in the headspace. The radon activities in headspace will then determine by a semiconductor detector e.g. RAD7, the electronic radon detector (Durridge, USA). The detector convert the alpha radiation from the radon decay products (primarily ${ }^{218} \mathrm{Po}$ ) into electrical signals and have a measurement range of 4 to $400,000 \mathrm{~Bq} / \mathrm{m}^{3}$ [17].

Longitudinal and time-series radon samplings are two common approaches used to trace and quantify groundwater discharge in a system. The former sampling technique involved collection of discrete water samples followed by in-situ sample analysis is convenient and provides instantaneous values of radon activity in the water. Sometimes, radon samples were measured in laboratory within 24 hours of sampling time if the in-situ measurement is not accessible. This sampling strategy provides a fast and cost-effective way to locate the groundwater discharge hotspots within a large scale study area [18]. Time-series sampling technique on the other hand, provides a near real-time concentration of radon activities in a single sampling point. This sampling strategy is normally applied in area where the groundwater hotspots was found and a high-resolution radon measurements are needed to better quantify the exchange fluxes between groundwater-surface water $[10,15,19]$.

Setiu Wetlands is located in the eastern coast of Peninsular Malaysia. The entire coastal zone of Setiu is characterized by wide sandy undulating landscape, consists a series of shore-parallel beach ridges and sandy swales. Setiu wetland is located on the low-lying sandy swales surrounded by elevated paleo-beach ridges. Since 1980s, the natural drainage system in this area was heavily modified to support local agricultural and aquaculture activities. Some of the natural streams were straightened and widened to facilitate the water supply. Additional artificial channels cutting perpendicular through the ridges were built to fulfil the water demands associated to agricultural practices. Besides agricultural and aquaculture activities, local communities' livelihood in this area is highly dependent on the natural resources found in the wetlands. Fish and shrimp farming, molluscan shellfish (e.g. gastropods and bivalves) aquaculture and harvesting, and commercial fishing are the major economic activities of the local populations in the area.

Setiu Wetlands has been subjected to increasing environmental pressures due to rapid growth of aquaculture and agricultural activities [20]. The excess nutrients from the pond could potentially leak into the groundwater. The polluted groundwater is non-point source pollution which may cause additional environmental pressure to Setiu Wetlands. In addition, the intensive farming activities on the beach ridges adjacent to lagoon may also contribute nutrients into the lagoon [21].

Previous study shows that Berombak Lake has contributed significant nutrients to Setiu Wetlands lagoon [22]. However, there has been no study on groundwater discharge as parts of the nutrient budget of drainage channel that connecting the lake and lagoon. Hence, this study is conducted to (i) identify the groundwater discharge hotspots along the drainage channels (hereinafter refer as Ular River) and (ii) quantify the groundwater fluxes and its associated nutrients to the surface water.

\section{Materials and Methods}

\section{Study area}

Ular River is a tributary of the Setiu Wetlands Lagoon, Terengganu, Malaysia. The river stretch between the coordinates $5^{\circ} 40^{\prime} 05.06^{\prime \prime} \mathrm{N}$ to $5^{\circ} 40^{\prime} 45.04^{\prime \prime} \mathrm{N}$ and $102^{\circ} 41^{\prime} 40.51^{\prime \prime} \mathrm{E}$ to $102^{\circ} 42^{\prime} 54.04^{\prime \prime} \mathrm{E}$. The river is approximately 4 
$\mathrm{km}$ in length, connected to its headwaters the Berombak Lake by two channels branches split about $2 \mathrm{~km}$ from the river mouth. The total size of river catchment is approximately $48,000 \mathrm{~m}^{2}$ and the average river depth is ranging from 0.1-1.8 m. The river receives freshwater input primarily from the Berombak Lake but one-fourth of the river from the downstream is subjected to saline water intrusion (Figure 1). The riverbed materials of upper part river, approximately $1.5 \mathrm{~km}$ from the river mouth is dominated by the fluvial deposits, followed by the middle part of river is dominated by the fluvial sand and marine mud. The lower part of river is dominated by the estuarine deposits. This estuarine deposits mainly consists of cohesive sediments with the combination of clay, silt and organic matter [23].

\section{Surface water and groundwater sampling}

Three longitudinal surface and groundwater sampling were conducted in Ular River in 2015. The first sampling is carried out in January 2015, followed by second and third samplings in March 2015 and May 2016. The first sampling was conducted during wet season, where the studied area received $152 \mathrm{~mm}$ of rain in the week prior to sampling in January 2015. On the other hand, March was the driest month of 2015 with less than $30 \mathrm{~mm}$ monthly rainfall while May 2016 recorded less than $35 \mathrm{~mm}$ of rainfall a week prior the sampling, making it a perfect timing to obtain the representative samples for dry season base-flow condition [24]. A total of 40 surface water and 19 groundwater samples were collected for radon and nutrient analysis.

For groundwater sampling, three piezometers were installed in riparian zone along Ular River (P1-P3, Figure 1). The boreholes were dug using a vibracorer to the depth of $\sim 3 \mathrm{~m}$. Slotted PVC pipes (drilled with $0.5 \mathrm{~cm}$ diameter holes, extended from the base of the pipe for $\sim 30 \mathrm{~cm}$ ) were placed into borehole and backfilled with the excavated materials. A cement grout was installed at the top of borehole to prevent surface water from moving via a preferential pathway into the piezometer. After installation, the piezometers were developed using a peristaltic pump until the discharge groundwater was clear. Besides piezometers, five addition groundwater samples were also collected from the nearby private groundwater wells (B1-B5, Figure 1). The depth of these groundwater wells ranges from 5 to $7 \mathrm{~m}$ below ground, and the groundwater samples were collected from water tap attached to the automatic submersible pumps.

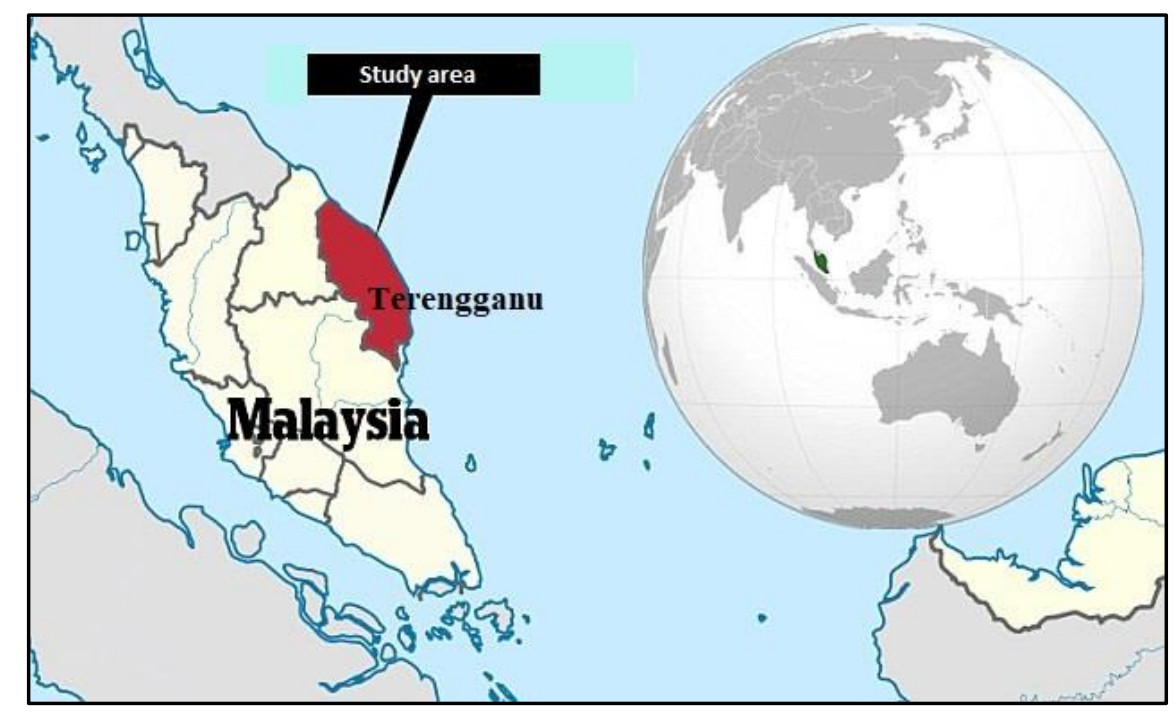




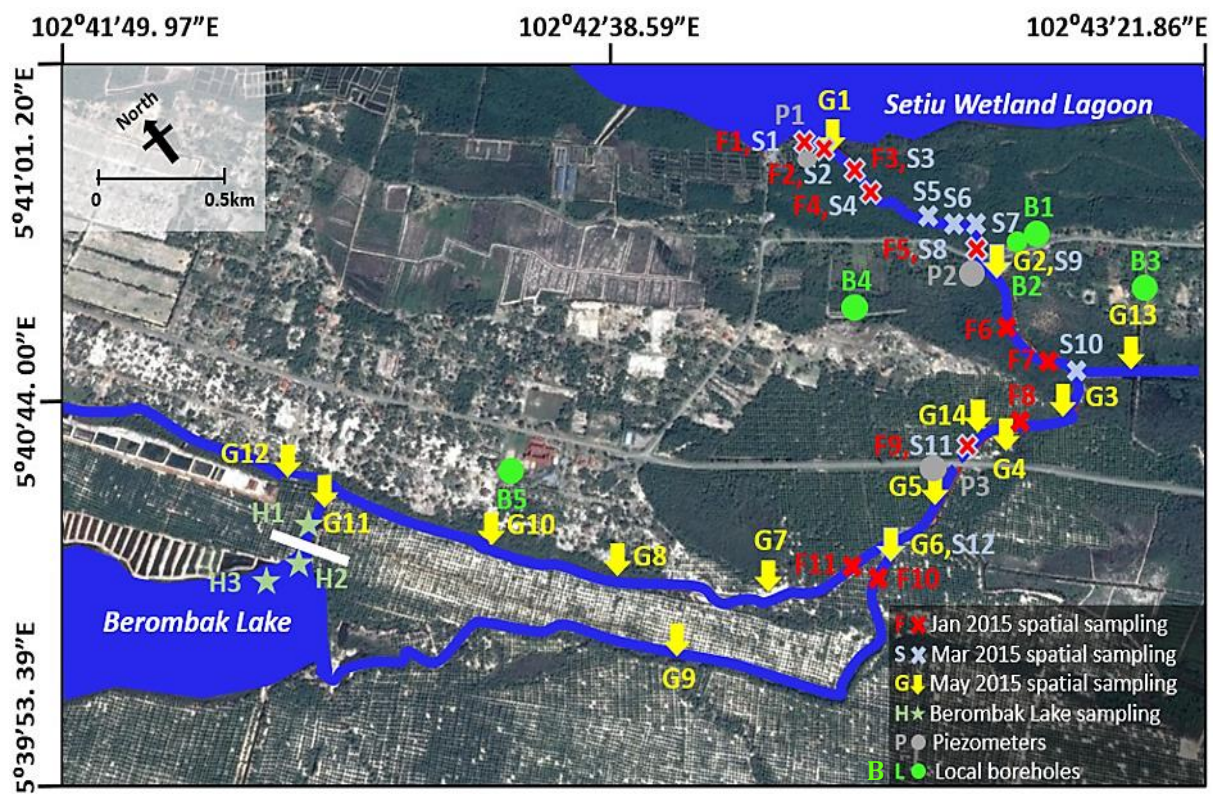

Figure 1. Location of Ular River and its sampling sites

\section{Radon analysis}

Surface water and groundwater samples for the radon concentration were collected using a Schott gas-tight glass bottle (500 ml, Duran, Germany) and stored under $10{ }^{\circ} \mathrm{C}$ prior to the analysis. The measurement of radon in water was conducted as proposed by Lee and Kim [25]. In general, the radon water sample was transferred to a gaswashing bottle with fitted disc ( $500 \mathrm{ml}$, Duran, Germany). The bottle was then connected to a desiccant column and RAD7 with a closed air loop circulation system. A desiccant column was installed between the gas washing bottle and RAD7 to reduce the moisture content in the radon detector. The internal pump in the RAD7 was set to $\sim 1 \mathrm{~L} / \mathrm{min}$ to provide a continuous air flow within the experimental setup. The equilibrium time for radon concentration equilibrium between water and recirculating air take approximately 15 minutes. Each radon sample was counted for two hours in order to yield good counting statistics. For actual radon concentration report, data reduction was performed by taking account of the radon decay activities during the time lapse between sample collection and analysis.

\section{Nutrient analysis and physico-chemical parameters measurement}

One liter of groundwater and surface water samples were collected and filtered through $0.45 \mathrm{~mm}$ cellulose acetate membrane. The filtrate was stored in acid prewashed HDPE bottle, chilled with ice and transported back to the lab for nutrients analyses. The measurement of ammonium, $\mathrm{NH}_{4}{ }^{+}-\mathrm{N}$ (Phenate Method, $4500-\mathrm{NH}_{4}{ }^{+}-\mathrm{G}$ ), nitrite, $\mathrm{NO}_{2}{ }^{-} \mathrm{N}$ (Colorimetric Method, 4500- $\mathrm{NO}_{2}^{-}-\mathrm{B}$ ), nitrate $\mathrm{NO}_{3}{ }^{-} \mathrm{N}$ (Automated Cadmium Reduction Method, 4500- $\mathrm{NO}_{3}^{-}-\mathrm{F}$ ) and phosphate $\mathrm{PO}_{4}{ }^{3-}-\mathrm{P}$ (Ascorbic Acid Method, 4500-P-E) concentrations were conducted by standard spectrophotometric techniques [26]. $\mathrm{pH}$, dissolved oxygen, salinity and water temperature of the surface water and groundwater were measured in-situ using a pre-calibrated YSI Professional Plus multiparameter Sonde (Xylem Inc. USA).

\section{Radon mass balance model}

In this study, radon mass balance method was used to estimate groundwater discharge rate. This method could provide an excellent time-integrated estimation of groundwater flux [20]. Figure 2 shows that the net radon concentration in a system can be inferred through the quantification of its sources and sink. The radon sources in surface water include the groundwater discharge, diffusive benthic flux and radioactive decay from the radon parental isotope, ${ }^{226} \mathrm{Ra}$ in the water column while atmospheric evasion or outgassing is the only sink for radon in surface water. 


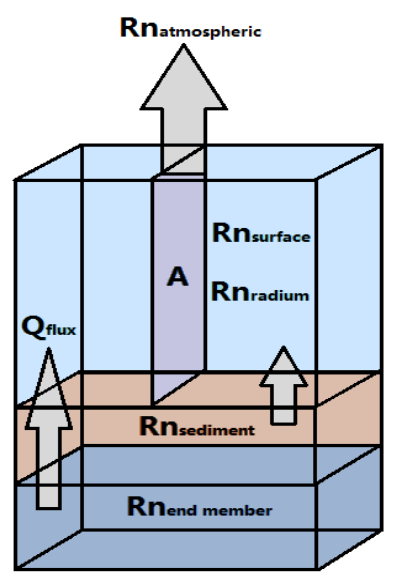

Figure 2. Radon mass balance model

Changes in groundwater flux $\left(\mathrm{Q}_{\text {flux }}\right)$ within a river can be expressed as:

$$
Q_{\text {flux }}=\frac{\mathrm{Rn}_{\text {surface }}+R n_{\text {atmospheric }}-R n_{\text {radium }}-R n_{\text {sediment }}}{R n_{\text {end }} \text { member }} \times D_{v}
$$

$Q_{f l u x}$ is the groundwater flux, expressed as $m^{3} d^{-1} ; \mathrm{Rn}_{\text {suface }}$ is the radon concentration in the surface water of Ular River $\left(B q / m^{3}\right) ; \mathrm{Rn}_{\text {atmospheric }}$ is the radon loss to the atmosphere $\left(B q / m^{2}\right.$ day); $\mathrm{Rn}_{\text {radium }}$ is the radon contributed by radium-226 in the surface water $\left(B q / \mathrm{m}^{3}\right) ; \mathrm{Rn}_{\text {sediment }}$ is the radon contributed by the sediment diffusion in the water column $\left(B q / m^{2}\right.$ day); $\mathrm{Rn}_{\text {end-member }}$ is the radon concentration in the groundwater end-member $\left(B q / \mathrm{m}^{3}\right)$ and $D_{v}$ is the total riverine discharge rate $\left(\mathrm{m}^{3} /\right.$ day $)$ in Ular River.

Total riverine discharge rate $\left(D_{v}\right)$ was obtained by the multiply the average current velocity $\left(\mathrm{ms}^{-1}\right)$ with the average cross-sections of the river $\left(\mathrm{m}^{2}\right)$. The velocity distribution in the river was measured by a handheld velocity flowmeter (Hach Co. USA), while the cross-sections and the average water depth of the river was measured using a measuring tape.

Fourteen surface water samples (40L each) were brought back to the lab for radium $\left(\mathrm{Rn}_{\text {radium }}\right)$ measurement. The measurement of $\mathrm{Rn}_{\text {radium }}$ followed method as described in [16, 27]. In general, the radium samples were first preconcentrated by passing the water samples through the manganese oxide impregnated fiber inside a PVC cartridge (Figure 3). The cartridge was $250 \mathrm{~mm}$ in length, $50 \mathrm{~mm}$ in diameter clear PVC tube coupled with a $50 \mathrm{~mm}$ PVC end cap and Union at both ends. Two brass ball valves with thread tape were then installed on the end cap and Union. The loaded manganese cartridge after the pre-concentration step was sealed inside the air-tight cartridge and left for 14 days in order to achieve ${ }^{226} \mathrm{Ra}$ and ${ }^{222} \mathrm{Rn}$ secular equilibrium [27]. The measurement of radon contributed by ${ }^{226} \mathrm{Ra}$ in the surface water was completed by RAD7.

The measurement of diffused radon rate from the sediment $\left(\mathrm{Rn}_{\text {sediment }}\right)$ was carried at $\mathrm{G} 1, \mathrm{G} 2$ and G5 (represent upstream, middle and downstream of Ular River, respectively, see Figure 1). At each sampling site, three $50 \mathrm{~mm}$ diameter PVC corers were hand-pushed into the riverbed and the corer was retrieve and transfer into glass Erlenmeyer flask. The flask was capped with rubber bunks after filling up with overlying river water. The sediment cores were then transported back to lab and incubated at room temperature for three weeks. The incubation allowed the radon in overlying water to achieve equilibrium with the diffusive inputs from the underlying sediments. The overlaying water was carefully transferred from each core into a gas washing bottle and analyzed by RAD7 at the end of the incubation period. Additional sediment core samples were collected by using $20 \mathrm{~mm}$-diameter HDPE tubes for both bulk density and sediment porosity test as described in previous study [28]. 


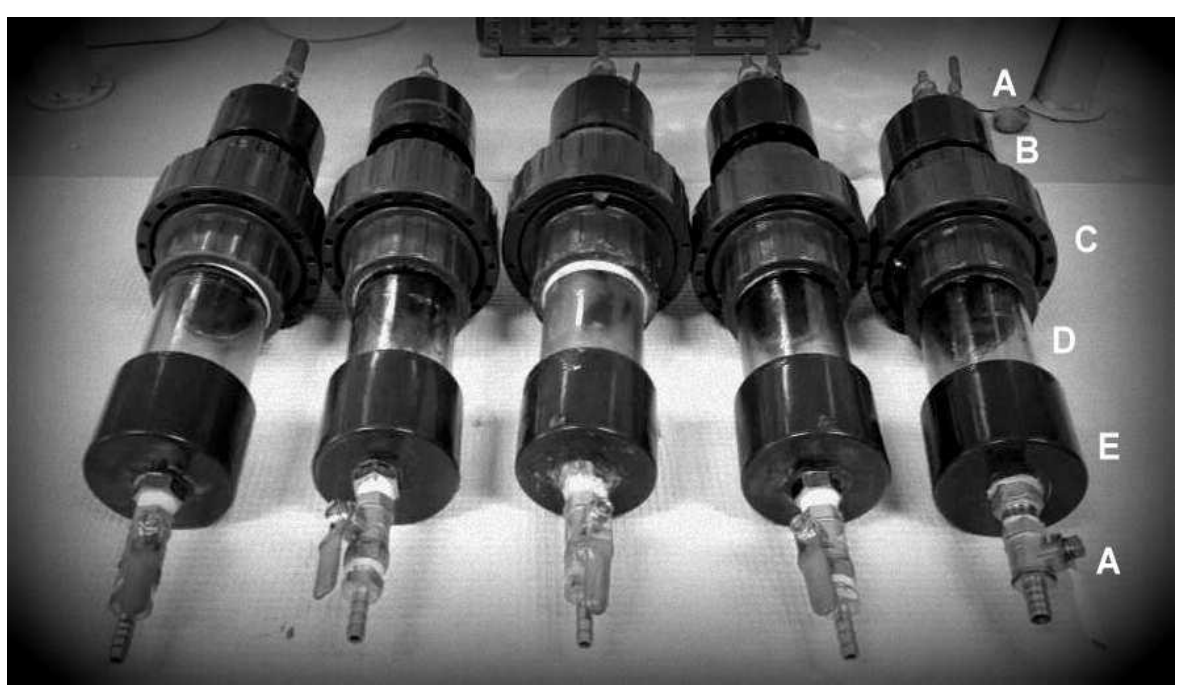

Figure 3. Design of Manganese Oxide cartridges; The brass valves (A), the PVC plug (B), the union with O-ring (C), the clear PVC pipe (D), and the end cap (E)

Radon diffusive flux from the sediment $\left(\mathrm{Rn}_{\text {sediment }}\right)$ was calculated based on [6, 28]:

$$
\begin{aligned}
& R n_{\text {sediment }}=\left(\lambda D_{S}\right)^{\frac{1}{2}}\left(C_{e q}-C_{0}\right) \\
& D_{S}=D_{m} /\left(1-\ln \left(\varnothing^{2}\right)\right. \\
& \left.-\log D_{m}=(980 / T)+1.59\right]
\end{aligned}
$$

where $R n_{\text {sediment }}$ is the radon contributed by sediment diffusion, expressed as $B q / m^{2} d a y ; \lambda$ represents the radon decay constant $\left(0.181\right.$ day $\left.^{-1}\right) ; C_{e q}$ is the radon released by radium in the sediments during sediment incubation experiments describe above, $C_{0}$ is the radon concentration detected in the overlying water before incubation experiment, $D_{s}$ represents the effective wet bulk sediment diffusion coefficient $\left(\mathrm{m}^{2} \mathrm{day}^{-1}\right), T$ is the water temperature and $\phi$ is the sediment porosity.

Porosity of the sediment can be calculated using equation 5 below:

$$
\varnothing=\frac{\left(\frac{W_{D}}{\rho_{w}}\right)}{\left(W_{D} / \rho_{w}\right)+\left(1-W_{D} / \rho_{d r y}\right)}
$$

where $W_{D}$ represents the water fraction presents in the sediments; $\rho_{w}\left(\mathrm{~g} / \mathrm{cm}^{3}\right)$ represents the water density of the surface water and $\rho_{d r y}\left(\mathrm{~g} / \mathrm{cm}^{3}\right)$ represents the dry grain density measured by dividing oven-dry soil weight with the volume of soil solids.

\section{Atmospheric evasion}

A seven-hour continuous measurement of radon-in-air by two units of RAD7s next to downstream (G1) and upstream (G5) sites was conducted to estimate the radon loss from the river through atmospheric evasion. The radon loss due to atmospheric evasion was calculated by using the following equation 6 :

$$
R n_{\text {atmophere }}=k\left(C_{w}-\propto C_{\text {atm }}\right)
$$


where $R n_{\text {atmosphere }}$ represents radon atmospheric evasion flux; $C_{w}$ is the radon concentration in river; $C_{a t m}$ represents radon concentration in the air; $\propto$ is the Ostwald's solubility coefficient $\left(0.2\right.$ at $\left.30^{\circ} \mathrm{C}\right)$ [29]; $k$ is the piston velocity or gas transfer velocity at water-air boundary. The piston velocity of radon can be inferred from wind and current velocity as mentioned in [30]. The $k$ value is calculated using equation 7 :

$$
k=1+1.719 w^{(0.5)} h^{-0.5}+2.58 u_{10}
$$

where $w$ is the water current velocity $\left(\mathrm{cms}^{-1}\right)$ in river measured by a handheld flowmeter (Hach, USA), $h$ is the effective depth of water exchanging with the atmosphere $(\mathrm{m})$, in this case, the average water depth of Ular River was adopted. $u_{10}$ is the wind speed $\left(\mathrm{ms}^{-1}\right)$ recorded by a portable digital anemometer (Kanomax, USA) on hourly basis during the radon-in-air sampling.

\section{Results and Discussion}

Variations of the water quality in Ular River during base flow and post-storm conditions

The physicochemical and nutrients data for all water samples are presented in Table 1. Figure 4a displays a clear seasonal variation of salt water intrusion in Ular River. During the dry period (March 2015), salt-wedge reached its maximum of $\sim 700 \mathrm{~m}$ from river mouth with the salinity ranged from 0.02 to $33.12 \mathrm{psu}$. In contrast, the water salinity stayed relatively fresh $(<2 \mathrm{ppt})$ during the post-storm period (January 2015) in Ular River.

Figure $4 \mathrm{~b}$ shows higher radon concentration (average: $620 \mathrm{~Bq} / \mathrm{m}^{3}, \mathrm{n}=8$ ) observed after the storm event as compared to the dry period (average: $248 \mathrm{~Bq} / \mathrm{m}^{3}, \mathrm{n}=8$ ). Higher radon concentration during the post-storm event could be the result of increased groundwater influx from the shallow aquifer into the river basin [34]. Rapid increase of groundwater table during the storm period could increase the hydrostatic pressure thus increase the lateral groundwater discharge into adjacent river [31,32]. Level of radon recorded during post-storm was at least one magnitude higher compared to the dry period, indicates high portion of groundwater contributing to storm flow generated in Ular River.
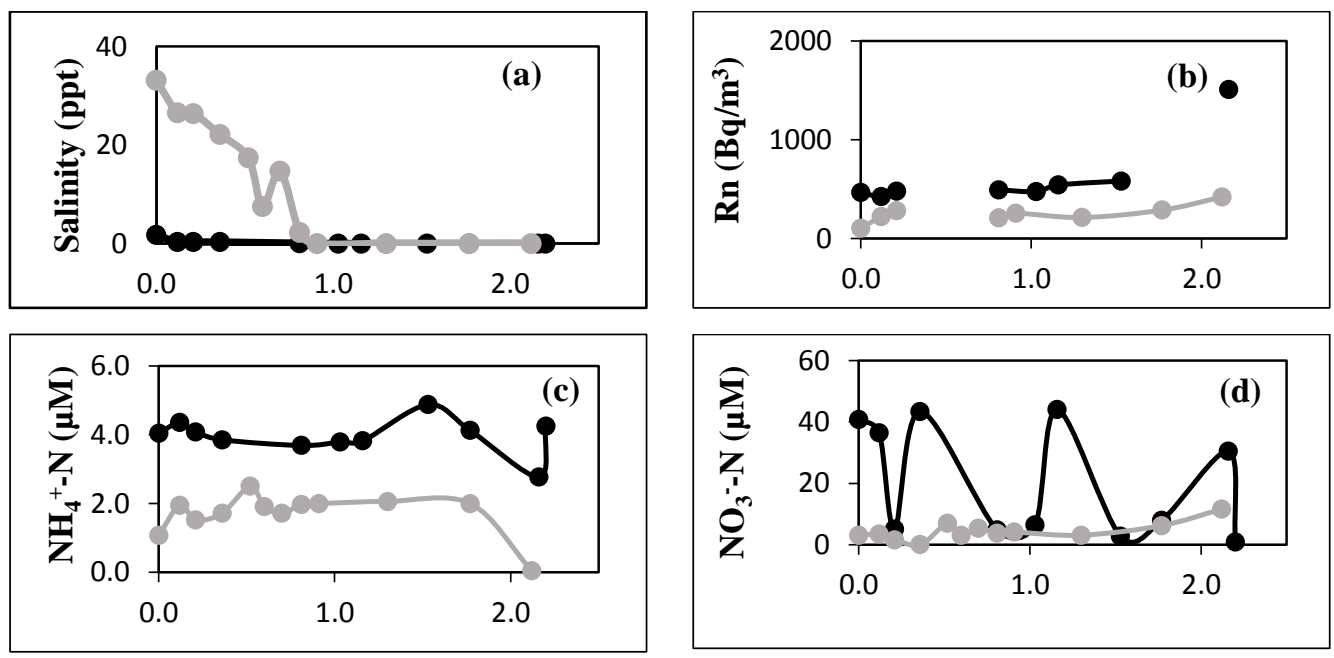
Ng \& Poh: QUANTIFICATION OF GROUNDWATER-DERIVED NUTRIENTS INTO BEACH RIDGE

DRAINAGE USING RADON MASS BALANCE MODEL

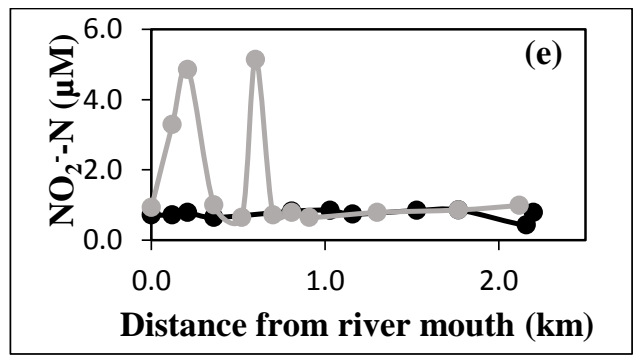

Figure 4. Longitudinal variation of salinity, radon and nutrient parameters in Ular River against distance from the river mouth; post-storm period (Jan 2015) in black and dry period (March 2015) in grey

Table 1. Physicochemical and nutrient data for both surface and groundwater

\begin{tabular}{|c|c|c|c|c|c|c|c|c|c|c|c|c|}
\hline & Site & Latitude & $\underset{\circ}{\text { Longitude }}$ & $\begin{array}{c}\text { DO } \\
\mathrm{mg} / \mathrm{L}\end{array}$ & pH & ${ }^{\circ} \mathbf{C}$ & $\begin{array}{c}\text { Salinity } \\
\text { ppt }\end{array}$ & $\begin{array}{c}\text { Phosphat } \\
\text { e } \mu \mathrm{M}\end{array}$ & $\begin{array}{c}\text { Ammonia } \\
\mu \mathrm{M}\end{array}$ & $\begin{array}{c}\text { Nitrate } \\
\mu \mathrm{M}\end{array}$ & $\begin{array}{c}\text { Nitrite } \\
\mu \mathrm{M}\end{array}$ & $\begin{array}{c}\text { Radon } \\
\text { Bq/L }\end{array}$ \\
\hline \multirow{11}{*}{ 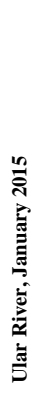 } & $\mathrm{F} 1$ & 5.67878 & 102.71206 & 4.67 & 7.51 & 26.9 & 1.75 & 0.02 & 4.05 & 40.9 & 0.71 & 0.47 \\
\hline & $\mathrm{F} 2$ & 5.67789 & 102.71294 & 4.02 & 6.10 & 27.1 & 0.34 & $<\mathrm{LOD}$ & 4.35 & 36.4 & 0.71 & 0.42 \\
\hline & F3 & 5.67647 & 102.71317 & 3.73 & 5.99 & 27.3 & 0.31 & $<\mathrm{LOD}$ & 4.08 & 5.01 & 0.79 & 0.48 \\
\hline & F4 & 5.67600 & 102.71314 & 3.66 & 5.97 & 27.6 & 0.32 & $<\mathrm{LOD}$ & 3.85 & 43.4 & 0.64 & N/A \\
\hline & F5 & 5.67306 & 102.71472 & 3.68 & 5.91 & 28.6 & 0.08 & $<\mathrm{LOD}$ & 3.69 & 4.75 & 0.82 & 0.49 \\
\hline & F6 & 5.67092 & 102.71472 & 3.53 & 5.59 & 29.2 & 0.02 & 0.03 & 3.78 & 6.44 & 0.85 & 0.47 \\
\hline & F7 & 5.66933 & 102.71397 & 3.35 & 5.57 & 29.7 & 0.02 & $<\mathrm{LOD}$ & 3.82 & 44.1 & 0.74 & 0.54 \\
\hline & F8 & 5.66881 & 102.71383 & 3.39 & 5.65 & 29.6 & 0.02 & $<\mathrm{LOD}$ & 4.87 & 2.73 & 0.84 & 0.58 \\
\hline & F9 & 5.66903 & 102.71106 & 3.43 & 5.57 & 29.6 & 0.02 & $<\mathrm{LOD}$ & 4.13 & 7.93 & 0.86 & N/A \\
\hline & F10 & 5.66792 & 102.70772 & 3.42 & 5.40 & 27.1 & 0.02 & $<\mathrm{LOD}$ & 2.77 & 30.43 & 0.43 & 1.51 \\
\hline & F11 & 5.66825 & 102.70769 & 3.34 & 5.49 & 30.0 & 0.01 & $<\mathrm{LOD}$ & 4.25 & 0.86 & 0.79 & N/A \\
\hline \multirow{12}{*}{ 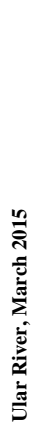 } & S1 & 5.67875 & 102.71257 & 5.96 & 6.80 & 31.8 & 33.1 & 0.06 & 1.07 & 3.00 & 0.93 & 0.10 \\
\hline & S2 & 5.67788 & 102.71298 & 2.81 & 7.94 & 33.9 & 26.5 & 0.03 & 1.95 & 3.43 & 3.29 & 0.22 \\
\hline & S3 & 5.67647 & 102.71317 & 4.25 & 7.66 & 32.1 & 26.4 & $<\mathrm{LOD}$ & 1.52 & 1.57 & 4.86 & 0.28 \\
\hline & S4 & 5.67573 & 102.71342 & 3.55 & 7.58 & 33.2 & 22.2 & $<\mathrm{LOD}$ & 1.72 & $<\mathrm{LOD}$ & 1.00 & N/A \\
\hline & S5 & 5.67418 & 102.71457 & 5.46 & 7.90 & 33.5 & 17.4 & $<\mathrm{LOD}$ & 2.50 & 7.00 & 0.64 & N/A \\
\hline & S6 & 5.67367 & 102.71500 & 4.43 & 7.49 & 33.5 & 7.53 & $<\mathrm{LOD}$ & 1.91 & 3.00 & 5.14 & N/A \\
\hline & S7 & 5.67343 & 102.71485 & 4.65 & 7.48 & 33.3 & 14.7 & $<\mathrm{LOD}$ & 1.72 & 5.36 & 0.71 & N/A \\
\hline & S8 & 5.67306 & 102.71472 & 5.30 & 7.84 & 32.8 & 2.27 & $<\mathrm{LOD}$ & 1.97 & 3.64 & 0.79 & 0.21 \\
\hline & S9 & 5.67248 & 102.71477 & 6.62 & 7.71 & 33.3 & 0.02 & $<\mathrm{LOD}$ & 2.00 & 4.07 & 0.64 & 0.26 \\
\hline & S10 & 5.66908 & 102.71472 & 6.00 & 8.47 & 35.3 & 0.03 & $<\mathrm{LOD}$ & 2.06 & 3.07 & 0.79 & 0.21 \\
\hline & S11 & 5.66903 & 102.71106 & 7.06 & 9.32 & 35.4 & 0.03 & $<\mathrm{LOD}$ & 2.00 & 6.21 & 0.86 & 0.29 \\
\hline & S12 & 5.66758 & 102.70770 & 6.91 & 8.12 & 33.0 & 0.03 & $<\mathrm{LOD}$ & 0.04 & 11.6 & 0.99 & 0.42 \\
\hline \multirow{14}{*}{ 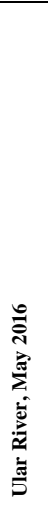 } & G1 & 5.67852 & 102.71234 & 1.79 & 7.22 & 33.1 & 27.7 & $<\mathrm{LOD}$ & 8.43 & 1.39 & 0.04 & 0.09 \\
\hline & G2 & 5.67228 & 102.71456 & 5.34 & 6.86 & 31.1 & 5.27 & $<\mathrm{LOD}$ & 4.03 & 0.66 & 0.03 & 0.05 \\
\hline & G3 & 5.66834 & 102.71395 & 4.31 & 7.42 & 33.6 & 21.1 & $<\mathrm{LOD}$ & 3.40 & 0.54 & 0.09 & 0.05 \\
\hline & G4 & 5.66806 & 102.71206 & 2.47 & 5.86 & 31.1 & 0.21 & $<\mathrm{LOD}$ & 4.53 & 2.69 & 0.08 & 0.09 \\
\hline & G5 & 5.66828 & 102.70960 & 6.06 & 5.90 & 31.6 & 0.03 & $<\mathrm{LOD}$ & 4.25 & 0.84 & 0.15 & 0.11 \\
\hline & G6 & 5.66754 & 102.70719 & 3.48 & 5.16 & 30.3 & 0.03 & $<\mathrm{LOD}$ & 0.29 & 0.14 & 0.11 & 0.19 \\
\hline & G7 & 5.66857 & 102.70468 & 7.46 & 6.39 & 34.0 & 0.03 & $<\mathrm{LOD}$ & 12.3 & 0.39 & 0.13 & 0.12 \\
\hline & G8 & 5.67118 & 102.70133 & 6.67 & 5.81 & 34.2 & 0.03 & $<\mathrm{LOD}$ & 14.2 & 1.99 & 0.07 & 0.21 \\
\hline & G9 & 5.66888 & 102.70164 & 2.55 & 4.16 & 30.8 & 0.03 & $<\mathrm{LOD}$ & 3.93 & 1.27 & 0.09 & 0.20 \\
\hline & G10 & 5.67400 & 102.69916 & 5.05 & 5.27 & 32.8 & 0.03 & $<\mathrm{LOD}$ & 15.6 & 0.12 & 0.05 & 0.20 \\
\hline & G11 & 5.67659 & 102.69529 & 3.30 & 4.56 & 32.2 & 0.03 & $<\mathrm{LOD}$ & 16.1 & 0.93 & 0.07 & 0.37 \\
\hline & G12 & 5.67782 & 102.69531 & 3.20 & 5.34 & 30.8 & 0.05 & $<\mathrm{LOD}$ & 27.2 & 0.09 & 0.03 & 0.13 \\
\hline & G13 & 5.66819 & 102.71607 & 1.89 & 6.88 & 33.3 & 0.02 & $<\mathrm{LOD}$ & 9.96 & 0.65 & 0.10 & N/A \\
\hline & G14 & 5.66941 & 102.71164 & 7.13 & 6.06 & 31.2 & 0.03 & $<\mathrm{LOD}$ & N/A & 0.93 & 0.15 & 0.07 \\
\hline \multirow{3}{*}{$\frac{\mathscr{s}}{\mathrm{s}}$} & $\mathrm{H} 1$ & 5.67581 & 102.69409 & 2.51 & 5.33 & 27.7 & 0.01 & N/A & $<\mathrm{LOD}$ & 1.69 & 0.26 & 1.90 \\
\hline & $\mathrm{H} 2$ & 5.67614 & 102.69494 & 4.48 & 5.66 & 29.0 & 0.01 & N/A & $<\mathrm{LOD}$ & 5.86 & 0.23 & 0.35 \\
\hline & $\mathrm{H} 3$ & 5.67581 & 102.69409 & 4.30 & 5.78 & 29.6 & 0.01 & N/A & 16.0 & 0.72 & 0.26 & 0.11 \\
\hline
\end{tabular}


Table 1 (cont'd). Physicochemical and nutrient data for both surface and groundwater

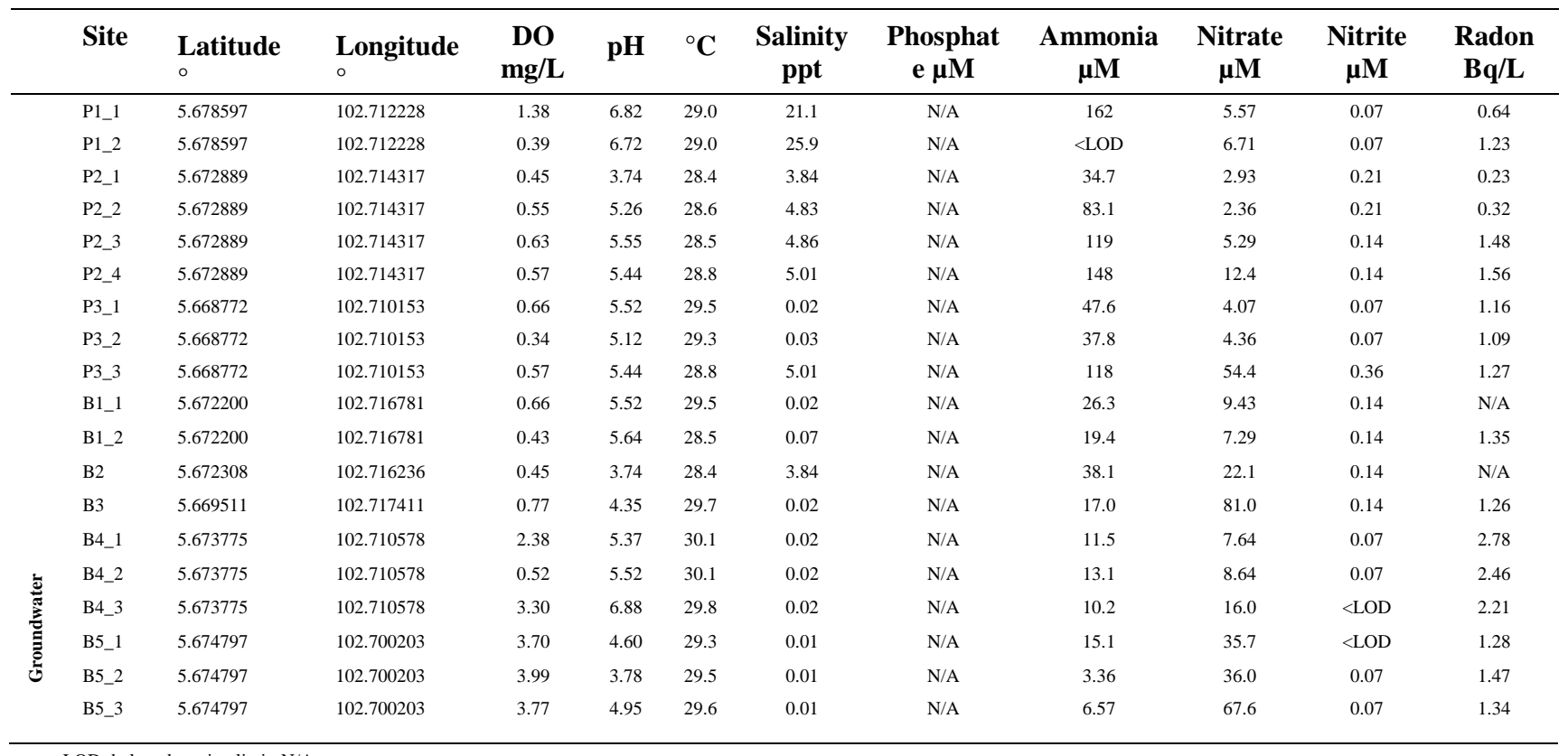

<LOD: below detection limit; N/A: no measurement

The radon level was found higher at the upstream (Figure $4 \mathrm{~b}$ and 5) and decreasing in concentration as the water flows downstream. This trend is probably due to significant dilution of radon concentration by the lagoon water at the river mouth, coupled with addition radioactive decay loss of the short half-life of radon during its transport down the river.

Ammonium and nitrate concentrations were higher in the post-storm sampling with an average of $3.97 \mathrm{NH}_{4}{ }^{+}-\mathrm{N} \mu \mathrm{M}$ and $20.3 \mathrm{NO}_{3}^{-}-\mathrm{N} \mu \mathrm{M}$ than to the dry season condition with $1.71 \mathrm{NH}_{4}{ }^{+}-\mathrm{N} \mu \mathrm{M}$ and $4.33 \mathrm{NO}_{3}{ }^{-} \mathrm{N} \mu \mathrm{M}$ recorded, respectively. However, both parameters showed no clear distribution trends in Ular River. Sources of nitrogen in the water body can be derived from agricultural runoff and sewage discharge from the residential area. Since groundwater often contains higher nitrogen concentrations than the surface water.

The average of $\mathrm{NO}_{2}{ }^{-}-\mathrm{N}$ and $\mathrm{PO}_{4}{ }^{3-}-\mathrm{P}$ during both dry period and post-storm sampling were $1.72 \mathrm{NO}_{2}^{-}-\mathrm{N} \mu \mathrm{M}$ and 0.01 $\mathrm{PO}_{4}{ }^{3-}-\mathrm{P} \mu \mathrm{M}$, and $0.74 \mathrm{NO}_{2}{ }^{-}-\mathrm{N} \mu \mathrm{M}$ and below detection limit $\left(\mathrm{PO}_{4}{ }^{3-} \mathrm{P}:<0.01 \mu \mathrm{M}\right)$, respectively. Nitrite and phosphate concentrations were found higher at downstream sites (Figure 3e, f). Higher nutrient concentrations observed at the downstream suggested possible input from the lagoon water. In contrary to most of the parameters studied, the concentrations of these nutrients were also higher during dry period.

\section{Radon inventory and groundwater discharge in Ular River}

The inventories for radon sources, sink, groundwater discharge rate and its associated nutrient fluxes are presented in Table 2. The average groundwater radon concentration obtained is $1061 \pm 665 \mathrm{~Bq} / \mathrm{m}^{3}$; this value is approximately three times higher than the average radon concentration of $358 \pm 246 \mathrm{~Bq} / \mathrm{m}^{3}$ observed in the surface water. Figure 5 shows that the groundwater discharge hotspots occur at upper and middle part of Ular River (G7-G12).

The radon loss through atmospheric evasion was calculated to be $4198 \pm 259 \mathrm{~Bq} / \mathrm{m}^{2} \mathrm{day}^{-1}$, which accounted for only about $0.01 \%$ of the total radon inventories studied in the model. Radon input contributed from the dissolved radium and sediment diffusion was also not insignificant. The radon inventories for both product of radium decay and sediment diffusion are $1.92 \pm 0.47 \mathrm{~Bq} / \mathrm{m}^{3}$ and $0.75 \pm 0.33 \mathrm{~Bq} / \mathrm{m}^{2}$ day, respectively. 
Ng \& Poh: QUANTIFICATION OF GROUNDWATER-DERIVED NUTRIENTS INTO BEACH RIDGE

DRAINAGE USING RADON MASS BALANCE MODEL

With the assumption of the river flow is steady and uniform, groundwater discharge rate in Ular River could account up to $6649 \pm 6178 \mathrm{~m}^{3} \mathrm{day}^{-1}$ (Table 2). Since the total riverine flow is a sum of surface water flow and the groundwater flow into the river, the percentage of groundwater flow contributed to the surface water can be calculated. the groundwater flow is equivalent to $\sim 33 \%$ of the total riverine flow in Ular River. This value is higher than most of the values reported elsewhere; where most estimation of the fresh groundwater fluxes into the river ranged from $0.6 \%-16 \%$ of the total riverine flow $[12,14,33]$.

Table 2. Radon inventories and mass balance input for radon box model

\begin{tabular}{|c|c|c|}
\hline Inventory & Symbol and Unit & Concentration \pm SD $(n)$ \\
\hline${ }^{222} \mathrm{Rn}$ in the surface water & $\mathrm{Rn}_{\text {surface }}\left(\mathrm{Bqm}^{-3}\right)$ & $358 \pm 246(14)$ \\
\hline${ }^{222} \mathrm{Rn}$ in the groundwater & $\mathrm{Rn}_{\text {end-member }}\left(\mathrm{Bqm}^{-3}\right)$ & $1061 \pm 665(17)$ \\
\hline \multicolumn{3}{|l|}{ Radon sources } \\
\hline${ }^{222} \mathrm{Rn}$ from the radium in water & $\mathrm{Rn}_{\text {radium }}\left(\mathrm{Bqm}^{-3}\right)$ & $1.92 \pm 0.47(6)$ \\
\hline${ }^{222} \mathrm{Rn}$ diffused from the sediment & $\mathrm{Rn}_{\text {sediment }}\left(\mathrm{Bqm}^{-2} \mathrm{day}^{-1}\right)$ & $0.75 \pm 0.33(6)$ \\
\hline \multicolumn{3}{|l|}{ Radon sinks } \\
\hline Atmospheric evasion & $\mathrm{Rn}_{\text {atmospheric }}\left(\mathrm{Bqm}^{-2}\right.$ day $\left.^{-1}\right)$ & $4198 \pm 259(2)$ \\
\hline \multicolumn{3}{|l|}{ Box model } \\
\hline River cross sections & $\mathrm{m}^{2}$ & $5.31 \pm 5.78(14)$ \\
\hline Current velocity & $\mathrm{ms}^{-1}$ & $0.11 \pm 0.13(13)$ \\
\hline Total riverine discharge & $D_{v}\left(m^{3}\right.$ day $\left.^{-1}\right)$ & $20355 \pm 19109(13)$ \\
\hline Groundwater discharge from aquifer & $\mathrm{Q}_{f l u x}\left(\mathrm{~m}^{3} \mathrm{day}^{-1}\right)$ & $6649 \pm 6178(13)$ \\
\hline \multicolumn{3}{|l|}{ Dissolved inorganic nutrient fluxes } \\
\hline Groundwater-derived $\mathrm{NH}_{4}^{+}-\mathrm{N}$ flux & molday $^{-1}$ & $2.88 \times 10^{2} \pm 2.67 \times 10^{2}(13)$ \\
\hline Groundwater-derived $\mathrm{NO}_{3}^{-}-\mathrm{N}$ flux & molday $^{-1}$ & $1.23 \times 10^{2} \pm 1.14 \times 10^{2}$ \\
\hline Groundwater-derived $\mathrm{NO}_{2}^{-}-\mathrm{N}$ flux & molday $^{-1}$ & $0.75 \pm 0.69(13)$ \\
\hline Total riverine $\mathrm{NH}_{4}^{+}-\mathrm{N}$ flux & molday $^{-1}$ & $1.93 \times 10^{2} \pm 1.74 \times 10^{2}(13)$ \\
\hline Total riverine $\mathrm{NO}_{3}-\mathrm{N}$ flux & molday $^{-1}$ & $18.7 \pm 16.9(13)$ \\
\hline Total riverine $\mathrm{NO}_{2}^{-}-\mathrm{N}$ flux & molday $^{-1}$ & $1.60 \pm 1.44(13)$ \\
\hline
\end{tabular}

Higher groundwater discharge rate in Ular River could be attributed to both geomorphological setting and aquifer's properties. The underlying material in study area is highly permeable. Lithological examination on borehole core samples suggests that the aquifer material throughout the river composed of generally fine sand with thin sandy silt $(\sim 10 \mathrm{~cm})$ found at the top layer while the rest of the aquifer materials $(\sim 300 \mathrm{~cm})$ are composed of coarse and fine sands with the porosity percentage between 17\%-26\% throughout the river bed. Figure 5 shows that high groundwater discharge rate (radon concentration) near G11 could be driven by topographic-gradients. G11 received water from Berombak Lake flow southward through a narrow beach ridges valley with high and steep riverbank $(+4 \mathrm{~m})$ created steep hydraulic gradient which induce more groundwater input to surface water. Furthermore, almost $90 \%$ of the Ular River catchment is occupied by oil palm plantation, the elevation of water table during irrigation may increase the hydraulic head pressure, intensify the groundwater discharge rate into the river basin. A combination of above mention factors resulted in a higher percentage of groundwater flow over the total riverine flow in Ular River. 

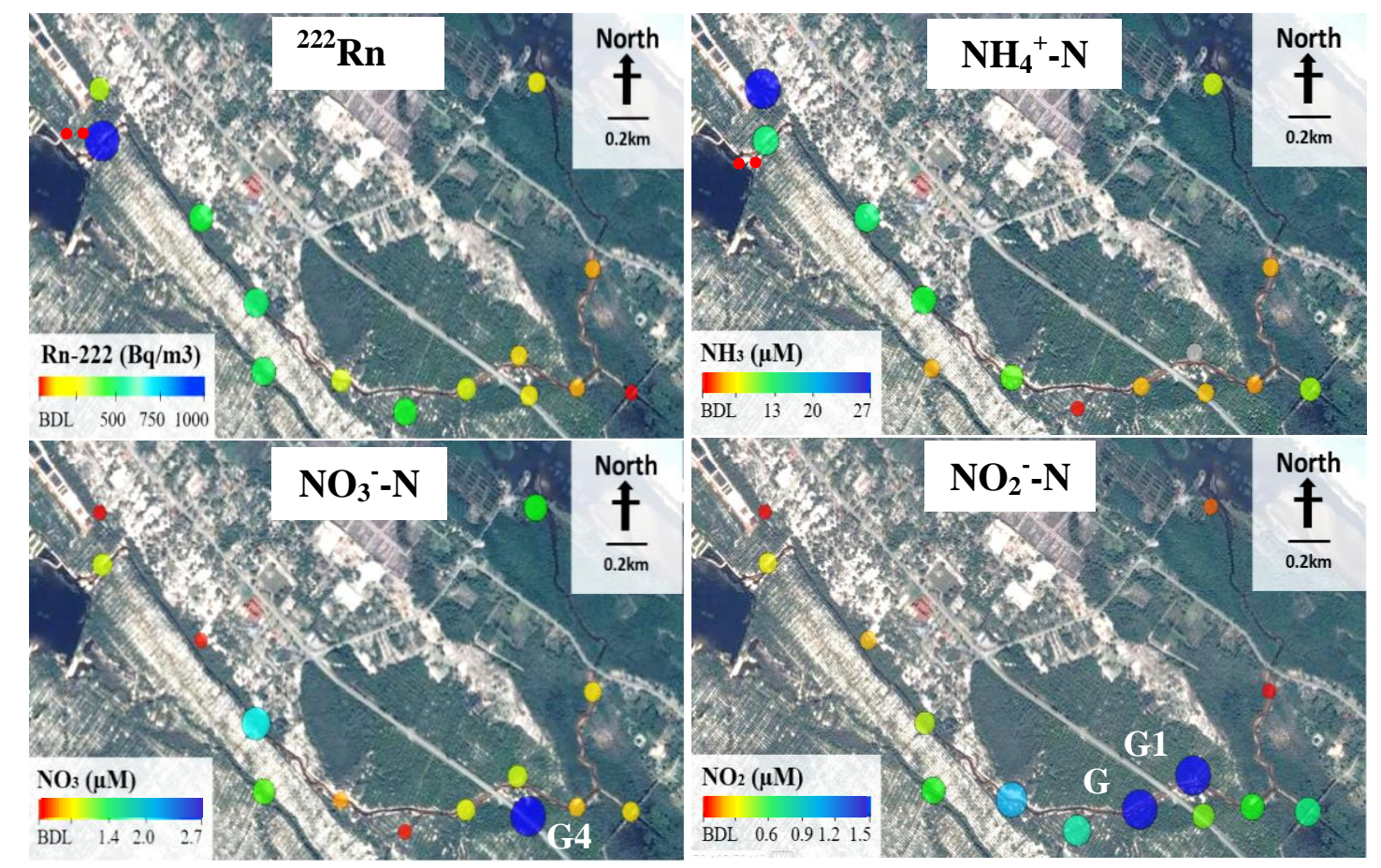

Figure 5. Radon and nitrogen-based nutrients distribution patterns in Ular River during May 2016 sampling. BDL = below detection limit: $\mathrm{NH}_{4}{ }^{+}-\mathrm{N}:<0.30 \mu \mathrm{M} ; \mathrm{NO}_{3}{ }^{-} \mathrm{N}:<0.10 \mu \mathrm{M} ; \mathrm{NO}_{2}{ }^{-}{ }^{-} \mathrm{N}:<0.14 \mu \mathrm{M}$.

\section{Groundwater-derived nutrient fluxes}

Groundwater sampling on May 2015 revealed a strong correlation between $\mathrm{NH}_{4}{ }^{+}-\mathrm{N}$ and radon concentrations in Ular surface water (Pearson correlation coefficient, r: 0.82, $\mathrm{p}<0.05$ ). Figure 5 illustrates that both $\mathrm{NH}_{4}{ }^{+}-\mathrm{N}$ and radon concentrations peaked approximately $4 \mathrm{~km}$ upstream from the estuary, decrease gradually to the downstream. We first suspect Berombak Lake to be the major source of ammonium however, $\mathrm{NH}_{4}{ }^{+}-\mathrm{N}$ concentration in Berombak Lake (H2, H3; Figure 5 \& Table 1) was below detection limit, suggesting that the contamination input was derived from the groundwater source rather than from the Berombak Lake. One of the plausible $\mathrm{NH}_{4}{ }^{+}-\mathrm{N}_{\text {contamination }}$ source could be came from the leakage of underground sewage septic tank located near to a residential area next to the oil palm plantation. Figure 5 also shows the concentration of $\mathrm{NO}_{3}{ }^{-} \mathrm{N}$ and $\mathrm{NO}_{2}{ }^{-} \mathrm{N}^{-}$reaching their maximum in G4, G5 and G14, respectively; suggesting that the surface runoff from oil palm plantation would be more likely to be the source of these nutrients.

Groundwater nutrient fluxes to Ular River can be calculated by multiply the groundwater discharge rate in the river with the nutrient concentrations of the groundwater end-member [4, 33]. Calculation from the radon mass balance model showed that the groundwater contributes an average of $2.88 \times 10^{2}$ molday $^{-1} \mathrm{NH}_{4}^{+}-\mathrm{N}_{1} 1.23 \times 10^{2}$ molday $^{-1} \mathrm{NO}_{3}^{-}$$\mathrm{N}$ and 0.75 molday ${ }^{-1} \mathrm{NO}_{2}^{-}-\mathrm{N}$ into the Ular River, respectively (Table 2). These nitrogen species in the groundwater are probably derived from the agricultural seepage from the surrounding oil palm plantation. Ammonium sources could also be derived from the sewage discharge from the nearby residential area located nearby the upstream of the Ular River. Underground storage tank leakage, septic system failure resulted in clogging and malfunction of the septic drain field could also lead to soil and groundwater contamination when the untreated wastewater recharge to the shallow aquifer.

\section{Conclusion}

This study successfully identified the groundwater discharge hotspots and its relationship with nutrients distribution in Ular River. The radon mass balance model results show that groundwater discharge 
Ng \& Poh: QUANTIFICATION OF GROUNDWATER-DERIVED NUTRIENTS INTO BEACH RIDGE

DRAINAGE USING RADON MASS BALANCE MODEL

represents a significant component of surface water balance accounted for about $33 \%$ of the total riverine flow. The strong correlation between radon and $\mathrm{NH}_{4}{ }^{+} \mathrm{N}$ suggested that the source of ammonium in Ular River is groundwater-derived. However, nitrate and nitrite showed insignificant correlation with radon indicating that the origin of these nutrients could be derived from the surface runoff. However, this study is only tracing the effects of groundwater-derived nutrient from one of the freshwater-fed drainage channel or tributaries connected to the Setiu lagoon and its nutrients contribution percentage. There are large portions of unaccounted groundwater-derived nutrients inputs from the other tributaries from the lagoon itself which are yet to be studied as part of the nutrient budget in Setiu Wetlands which may warrant further investigation by future studies. In overall, this investigation would allow coastal manager to assess the magnitude of groundwater discharge and its nutrients contribution into the Setiu Wetlands and highlighted significance of groundwater-based nutrients in riverine and estuarine nutrient budgets.

\section{Acknowledgement}

This work was also made possible through the funding from Ministry of Higher Education of Malaysia, Niche Research Grant Scheme (NRGS-53131). NCW wished to thank Malaysian Government for MyBrian15 scholarship.

\section{References}

1. Buddemeier, R. W. (1996). Groundwater discharge in the coastal zone. Ecological Economics, 35(200): 25-33. Burnett, W. C. Taniguchi, M. and Oberdorfer, J. (2001). Measurement and significance of the direct discharge of groundwater into the coastal zone. Journal of Sea Research, 46(2), 109-116.

2. Johnson, A. G., Glenn, C. R., Burnett, W. C., Peterson, R. N. and Lucey, P. G. (2008). Aerial infrared imaging reveals large nutrient-rich groundwater inputs to the ocean. Geophysical Research Letters, 35 (15): 1-6.

3. Lee, Y. W., Hwang, D. W., Kim, G., Lee, W. C. and Oh, H. T. (2009). Nutrient input from submarine groundwater discharge (SGD) in Masan Bay, an embayment surrounded by heavily industrialized cities, Korea. Science of the Total Environment, 407: 3181-3188.

4. Burnett, W. C., Aggarwal, P. K., Aureli, A., Bokuniewicz, H., Cable, J. E., Charette, M. A., Kontar, E., Krupa, S., Kulkarni, K. M. and Loveless, A. (2006). Quantifying submarine groundwater discharge in the coastal zone via multiple methods. Science of the Total Environment, 367: 498-543.

5. Cable, J. E., Burnett, W. C., Chanton, J. P. and Weatherly, G. L. (1996). Estimating groundwater discharge into the northeastern Gulf of Mexico using radon-222. Earth Planetary Science Letters, 144: 591-604.

6. Dulaiova, H., Gonneea, M. E., Henderson, P. B. and Charette, M. A. (2008). Geochemical and physical sources of radon variation in a subterranean estuary-implication for groundwater radon activities in submarine groundwater discharge studies. Marine Chemistry, 110, 120-127.

7. Lerman, A. (1979). Geochemical processes. Wiley-Interscience. New York: p. 481.

8. Schubert, M., Knoeller, K., Treutler, H.-C., Weiss, H. and Dehnert, J. (2006). ${ }^{222} \mathrm{Rn}$ as a tracer for the estimation of infiltration of surface waters into aquifers, in Radionuclides in the environment Povinec, P. P. and Sanchez-Cabeza,

9. J. A. (Editor). Radioactivity in the Environment, 8: 326-334.

10. Burnett, W. C. and Dulaiova, H. (2003). Estimating the dynamics of groundwater input into the coastal zone via continuous radon-222 measurements. Journal of Environmental Radioactivity, 69 (1-2): 21-35.

11. Mullinger, N. J., Binley, A. M., Pates, J. M. and Crook, N. P. (2007). Radon in Chalk streams: Spatial and temporal variation of groundwater sources in the Pang and Lambourn catchments, UK. Journal of Hydrology, 339: $172-182$.

12. Schwartz, M. C. (2003). Significant groundwater input to a coastal plain estuary: Assessment from excess radon. Estuarine, Coastal and Shelf Science, 56: 31-42.

13. Swarzenski, P.W., Orem, W.H., McPherson, B.F., Baskaran, M. and Wan, Y. (2006). Biogeochemical transport in the Loxahatchee river estuary: the role of submarine groundwater discharge. Marine Chemistry, 101: 248265.

14. Santos, I. R. and Eyre, B. D. (2011). Radon tracing of groundwater discharge into an Australian estuary surrounded by coastal acid sulphate soils. Journal Hydrology, 396: 246-257. 
15. Burnett, W. C., Peterson, R. N., Santos, I. R. and Hicks, R. W. (2010). Use of automated radon measurements for rapid assessment of groundwater flow into Florida streams. Journal of Hydrology. 380: 298-304.

16. Peterson, R. N., Burnett, W. C., Dimova, N. and Santos, I. R. (2009). Comparing measurement methods for radium-226 on manganese-fiber. Limnology and Oceanography. 7: 196-205.

17. Durridge Company Inc. (2014). RAD H2O user manual radon in water accessory.

18. Baskaran, M. (2016). Radon measurement techniques in: Radon: A tracer for geological, geophysical and geochemical studies. Springer Geochemistry: pp. 15-35.

19. Dulaiova, H., Peterson, R. N., Burnett, W. C. and Lane-Smith, D. (2005). A multi-detector continuous monitor for assessment of ${ }^{222} \mathrm{Rn}$ in the coastal ocean. Journal of Radioanalytical and Nuclear Chemistry, 263, 361-365.

20. Najilah, M., Nadirah, M., Sakri, I. and Shaharom-Harrison, F. (2010). Bacteria associated with wild mud crab (Scylla serrata) from Setiu Malaysia with emphasis on antibiotic resistance. Pakistan Journal of Biological Sciences, 13(6): 293-297.

21. Suratman, S., Mohd Tahir, N., Jusoh, S. R. and Ariffin, M. M. (2005). Assessment of anthropogenic effects on water quality in Setiu Wetland, Terengganu. Sains Malaysiana, 34: 87-92.

22. Suratman, S., Hussein, A. N. A. R., Mohd Tahir, N., Latif, M. T., Mostapa, R. and Weston, K. (2016). Seasonal and spatial variability of selected surface water quality parameters in Setiu Wetlands, Terengganu, Malaysia. Sains Malaysiana, 45(4): 551-558.

23. Rosnan, Y., Mohd, L.H. and Noor, A. M. S. (1995). Grain-size distribution of sediment in the vicinity of Setiu lagoon-estuary system. Pertanika Journal of Tropical Agricultural Science, 18(1): 71-76.

24. Department of Irrigation and Drainage Malaysia (2016). Flood information. Access from http://infobanjir.water.gov.my/. [Access date on 10 October 2016].

25. Lee, J-M. and Kim, G. (2006). A simple and rapid method for analyzing radon in coastal and groundwaters using a radon-in-air monitor. Journal of Environmental Radioactivity, 89(3): 219-228.

26. APHA. (2005). Standard methods for the examination of water and wastewater, $21^{\text {st }}$ edition. American Public Health Association, Washington, DC.

27. Kim, G., Burnett, W. C., Dulaiova, H., Swarzenski, P. W., Moore, W. S. (2001). Measurement of ${ }^{224}$ Ra and ${ }^{226} \mathrm{Ra}$ activities in natural waters using a radon-in-air monitor. Environmental Science and Technology, 35: 4680-4683.

28. Corbett, D., Burnett, W., Cable, J. E. and Clark, S. B. (1998). A multiple approach to the determination of radon fluxes from sediments. Journal of Radioanalytical and Nuclear Chemistry, 236: 247-252.

29. Clever, H. L. (1979). Solubility Data Series. Krypton, Xenon \& Radon-Gas solubilities. Pergamon Press, Oxford.

30. Dulaiova, H., and Burnett, W. C. (2006). Radon loss across the water-air interface (Gulf of Thailand) estimated experimentally from ${ }^{222} \mathrm{Rn}-{ }^{224} \mathrm{Ra}$. Geophysical Research Letters, 33(5): 1-4.

31. Hamada, H., Sukchan, S. and Putiso, M. (2005). Measurement of ${ }^{222}$ Rn concentrations in surface water in northern Thailand. Radioisotopes, 54: 315-320.

32. Fetter, C. W. (1994). Applied hydrogeology ( ${ }^{\text {rd }}$ Edition). McMillian, New York.

33. Charette, M. A. and Buesseler, K.O. (2004). Submarine groundwater discharge of nutrients and copper to an urban sub estuary of Chesapeake Bay (Elizabeth River). Limnology and Oceanography, 49(2), 376-385. 